\title{
穴あき板で仕切られた一次元音場の音響固有周波数の推定法に関する研究
}

\section{Study on a method for estimating acoustic natural frequency of one dimensional sound field partitioned by perforated plate}

\author{
Kunihiko ISHIHARA*1 and Satoru KUDO*2 \\ ${ }^{* 1}$, *2 Tokushima Bunri Univ. Dept. of Clinical Engineering \\ 1314-1 Shido, Sanuki-Shi, Kagawa 769-2193, Japan
}

Received: 16 January 2019; Revised: 28 May 2019; Accepted: 25 August 2019

\begin{abstract}
A perforated plate is used as an acoustic absorption material for compressors and acoustic barriers for roads and railways. The effects of the perforated plate on the acoustic natural frequency of an one dimensional sound field partitioned with the perforated plate has been studied in our previous investigations. And it was clarified that the acoustic natural frequency of the one dimensional sound field partitioned with the perforated plate becomes lower as the aperture ratio becomes smaller. There are two methods obtaining the acoustic natural frequencies. One is the method based on the eigenvalue analysis. And the other is the one based on the peak frequency of the response analysis. In this paper, the impedance derived by Melling is used for the response analysis. we compared two acoustic natural frequencies calculated by different two methods. As a result, it was clarified that the acoustic natural frequency calculated by the response analysis was a little smaller than that calculated by the eigenvalue analysis in all conditions. But its difference is small, and both the acoustic natural frequencies calculated by two methods agree with experimental results. And it has become easier to physically understand the analytical and experimental results by considering and comparing the element of transfer matrix.
\end{abstract}

Keywords : Noise control, Sound and acoustics, Acoustic natural frequency, Perforated plate, Transfer matrix method

\section{1. 緒言}

穴あき板は，産業界において圧縮機用消音器に対する吸音材（木村他，2009）や道路・鉄道用防音壁の吸音材 として用いられている（次橋他，2014）。また，熱交換器のダクト壁に穴あき板を適用して大音響騒音を抑制でき ることを確認している（石原他，2016），(石原，2017）。これらは穴あき板の吸音に着目した研究であるが，本研 究では，穴あき板で仕切られた一次元音場を対象として穴あき板の共鳴周波数（以下音響固有周波数）に及ぼす 影響について検討してきた（石原他，2017）。そして，実験や伝達マトリックス法による解析を行った結果，実験 と解析の結果はよく一致し, 開口率を減少させると音響固有周波数が下がることが明らかになった(石原他, 2017). また，この現象は音波が開口部を通過する際，時間遅れを生じ，見かけの音速が減少したものと解釈した（石原 他，2018）.さらにこれを明らかにするために，音の伝搬速度を求める実験を行い，見かけの音速が減少すること を確認した（工藤，石原，2017）。これまでは穴あき板で仕切られた一次元音場の音響固有周波数に及ぼす穴あき 板の開口率の影響について伝達マトリックス法によって導出した振動数方程式より共鳴周波数を求める手法（以

\footnotetext{
No.19-00016 [DOI:10.1299/transjsme.19-00016], J-STAGE Advance Publication date : 3 September, 2019

*1 正員，フェロー，徳島文理大学 保健福祉学部臨床工学科（†769-2193 香川県さぬき市志度 1314-1）

*2 正員, 徳島文理大学 保健福祉学部臨床工学科

E-mail of corresponding author: k-ishihara@fe.bunri-u.ac.jp
} 
下固有値解析）を用いてきた，そして先の研究では開口率のみならず穴の長さやダクト長手方向の設置位置の音 響固有周波数に及ぼす影響を明らかにし, 実駼結果とも比較してよく一致することを示した (石原, 工藤, 2019). 一方, 共鳴周波数を求める方法として, 応答解析を行い音圧レベルがピークとなる周波数を求めることもしばし ば行われる(以下応答解析)。その際には共振ピークが無限大にならないように穴部の音響インピーダンスを伝達 行列に適用する必要があり，その結果固有值解析とは行列の值が異なることになる．本論文では行列の值が異な ることで音響固有周波数にどのような影響があるのか，また固有值解析，応答解析のいずれの解析結果が実験值 によく合うのか，さらにすべての条件で忘答解析值が固有值解析值より小さく現れる点に着目し，その理由を明 らかにした点等に新規性を持たせた。したがって, 固有值解析に用いた伝達マトリックス法の穴あき板に対応す る行列において，穴あき板の減衰を考慮するために Melling の論文（Melling，1973）にある穴部のインピーダン スを適用し，伝達マトリックス法を用いた応答解析を行い音圧レベルのピークから共鳴周波数を計算した（以下 応答解析)。さらに, 実験結果と固有值解析結果および応答解析結果を比較し, 二つの解析方法の違いについて検 討を行った。これによって, 穴あき板で仕切られた一次元音場の共鳴周波数の推定に適した解析手法について知 見を得る.

\section{2. 固有值解析と応答解析}

\section{$2 \cdot 1$ 固有值解析の方法}

図 1 に示す一次元ダクトの断面変化する箇所および端部に図のように番号を付け，各位置での状態べクトルを $\left[\begin{array}{ll}P_{i} & U_{i}\end{array}\right]^{T} \quad(i=1 \sim 4)$ で表すと両端部の状態ベクトルの間には式（1）が成り立つ. ここで $P_{i}, \quad U_{i}$ はそれぞれ音圧 と体積速度である。

$$
\left[\begin{array}{l}
P_{4} \\
U_{4}
\end{array}\right]=\left[\begin{array}{cc}
\cos k l_{2} & j Z_{2} \sin k l_{2} \\
j \frac{1}{Z_{2}} \sin k l_{2} & \cos k l_{2}
\end{array}\right]\left[\begin{array}{cc}
\cos k l_{3} & j Z_{3} \sin k l_{3} \\
j \frac{1}{Z_{3}} \sin k l_{3} & \cos k l_{3}
\end{array}\right]\left[\begin{array}{cc}
\cos k l_{1} & j Z_{1} \sin k l_{1} \\
j \frac{1}{Z_{1}} \sin k l_{1} & \cos k l_{1}
\end{array}\right]\left[\begin{array}{l}
P_{1} \\
U_{1}
\end{array}\right]=\left[\begin{array}{ll}
A_{11} & A_{12} \\
A_{21} & A_{22}
\end{array}\right]\left[\begin{array}{l}
P_{1} \\
U_{1}
\end{array}\right]
$$
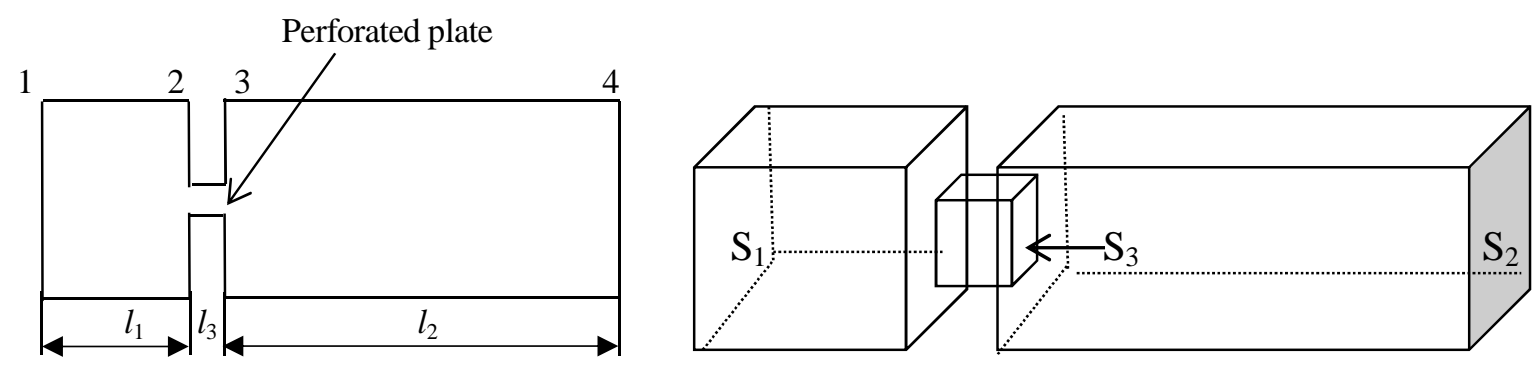

Fig.1 Analytical model of 1D duct.

ダクトの両端は閉であるので境界条件は次式で与えられる.

$$
U_{1}=0, \quad U_{4}=0
$$

この境界条件を式（1）に適用すると振動数方程式

$$
\left|A_{21}\right|=0
$$

を得る．ここで $A_{21}$ は式（4）で与えられる.

$$
A_{21}=j \frac{1}{Z_{2}} \sin k l_{2}\left(\cos k l_{3} \cos k l_{1}-\frac{Z_{3}}{Z_{1}} \sin k l_{3} \sin k l_{1}\right)+j \cos k l_{2}\left(\frac{1}{Z_{3}} \sin k l_{3} \cos k l_{1}+\frac{1}{Z_{1}} \cos k l_{3} \sin k l_{1}\right)
$$


開口率 $\varphi\left(S_{3} / S_{2}\right)$ の穴あき板を含む音響管の振動数方程式として最終的に式（5）が得られる.

$$
\sin k l_{2}\left(\cos k l_{3} \cos k l_{1}-\frac{1}{\varphi} \sin k l_{3} \sin k l_{1}\right)+\cos k l_{2}\left(\varphi \sin k l_{3} \cos k l_{1}+\cos k l_{3} \sin k l_{1}\right)=0
$$

式（5）において，開口率 $\varphi$ が $1 \% ， 4 \%$ よび $16 \%$ ときの音響固有振動数を穴あき板の穴の長さ $l_{3}$ が，0.0023 $\mathrm{m}, 0.0046 \mathrm{~m}, 0.01 \mathrm{~m}$ および $0.02 \mathrm{~m}, l_{1}$ および $l_{2}$ が， $l_{1}=0.434 \mathrm{~m}$ かつ $l_{2}=0.400 \mathrm{~m}$ および $l_{1}=0.634 \mathrm{~m}$ かつ $l_{2}=0.200 \mathrm{~m}$ の場合について計算した。 ここで， $S_{2} ， S_{3}$ はそれぞれダクト断面積と穴あき板の開口面積である.

\section{$2 \cdot 2$ 応答解析の方法}

応答解析では減衰の効果を考慮するために穴あき板の一個の穴の直径を用いて穴部のインピーダンスを計算し た．そのため，式（1）の伝達マトリックスにおける穴部に関する行列である

$$
\left[\begin{array}{cc}
\cos k l_{3} & j Z_{3} \sin k l_{3} \\
j \frac{1}{Z_{3}} \sin k l_{3} & \cos k l_{3}
\end{array}\right]
$$

を式（7）で示す行列に置き換えて式（8）により計算を行った.

$$
\begin{aligned}
& {\left[\begin{array}{cc}
1 & Z_{\mathrm{R}}+j Z_{\mathrm{i}} \\
0 & 1
\end{array}\right]} \\
& {\left[\begin{array}{l}
P_{4} \\
U_{4}
\end{array}\right]=\left[\begin{array}{cc}
\cos k l_{2} & j Z_{2} \sin k l_{2} \\
j \frac{1}{Z_{2}} \sin k l_{2} & \cos k l_{2}
\end{array}\right]\left[\begin{array}{cc}
1 & Z_{\mathrm{R}}+j Z_{\mathrm{i}} \\
0 & 1
\end{array}\right]\left[\begin{array}{cc}
\cos k l_{1} & j Z_{1} \sin k l_{1} \\
j \frac{1}{Z_{1}} \sin k l_{1} & \cos k l_{1}
\end{array}\right]\left[\begin{array}{l}
P_{1} \\
U_{1}
\end{array}\right]=\left[\begin{array}{ll}
A_{11} & A_{12} \\
A_{21} & A_{22}
\end{array}\right]\left[\begin{array}{l}
P_{1} \\
U_{1}
\end{array}\right]}
\end{aligned}
$$

ここで $Z_{\mathrm{R}}+j Z_{\mathrm{i}}$ は穴あき板の音響インピーダンスを示している. Melling の研究（Melling，1973）によれば穴 1 個 の特性インピーダンスは次式で与えられる.

$$
Z^{\prime}=\frac{l}{r_{0}} \sqrt{2 \rho \mu \omega}+j \omega \rho l\left[1+\frac{1}{r_{0}} \sqrt{\frac{2 \mu}{\rho \omega}}\right] \quad \text { for } \quad r_{0} \sqrt{\omega \rho / \mu}>10
$$

ここで $r_{0}, l$ はそれぞれ穴の半径と長さ， $\rho, \mu$ はそれぞれ空気の密度と粘性係数である. $\omega$ は角周波数である. 多くの穴があり，互いに干渉が無い場合の特性インピーダンス $Z_{R}+j Z_{i}$ は

$$
Z_{\mathrm{R}}+j Z_{\mathrm{i}}=Z^{\prime} \frac{S}{S_{3}}=\frac{Z^{\prime}}{\varphi} \quad(\varphi \text { : 開口率 })
$$

で与えられる．ここで $S_{3}$ は穴の面積， $\varphi$ は開口率， $S\left(=S_{1}, S_{2}\right)$ はダクトの断面積である.

式（8）において $P_{4}$ は境界条件， $U_{1}=1, \quad U_{4}=0$ を考慮すると式（11）で与えられる.

$$
P_{4}=\frac{-A_{11} A_{22}+A_{12} A_{21}}{A_{21}}
$$

式（11）を計算しピークを与える波数 $k$ より求めた周波数を共鳴周波数とした. ピークを与える周波数は式 (11) の分子が定数であるため $A_{21}$ の絶対值を最小にする周波数である. ただし $\mathrm{A}_{11} \sim \mathrm{A}_{22}$ は以下の式で与えられる. 
$\mathrm{A} 11=\cos k l_{2} \cos k l_{1}-\frac{Z_{i}}{Z_{1}} \cos k l_{2} \sin k l_{1}-\frac{Z_{2}}{Z_{1}} \sin k l_{2} \sin k l_{1}+j \frac{Z_{R}}{Z_{1}} \cos k l_{2} \sin k l_{1}$

$\mathrm{A} 12=Z_{R} \cos k l_{2} \cos k l_{1}+j\left[Z_{1} \cos k l_{2} \sin k l_{1}+Z_{i} \cos k l_{2} \cos k l_{1}+Z_{2} \sin k l_{2} \cos k l_{1}\right]$

$\mathrm{A} 21=-\frac{Z_{R}}{Z_{1} Z_{2}} \sin k l_{2} \sin k l_{1}+j\left[\frac{1}{Z_{2}} \sin k l_{2} \cos k l_{1}-\frac{Z_{i}}{Z_{2} Z_{1}} \sin k l_{2} \sin k l_{1}+\frac{1}{Z_{1}} \sin k l_{1} \cos k l_{2}\right]$

$\mathrm{A} 22=\left[\cos k l_{2} \cos k l_{1}-\frac{Z_{1}}{Z_{2}} \sin k l_{2} \sin k l_{1}-\frac{Z_{i}}{Z_{2}} \sin k l_{2} \cos k l_{1}\right]+j \frac{Z_{R}}{Z_{2}} \sin k l_{2} \cos k l_{1}$

\section{3. 実験方法}

\section{$3 \cdot 1$ 実験装置}

穴あき板の開口率や穴の長さの音響固有周波数に及ぼす影響を明らかにするための実験装置を図 2 , 図 3 に示 す. 穴あき板の設置位置は図 2 に示す 2 通りとした。 また, 眓 3 にスピーカの設置位置を示す. スピーカの口径

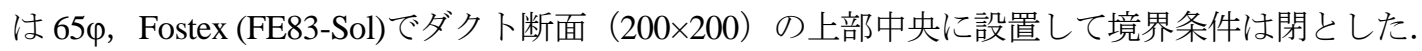
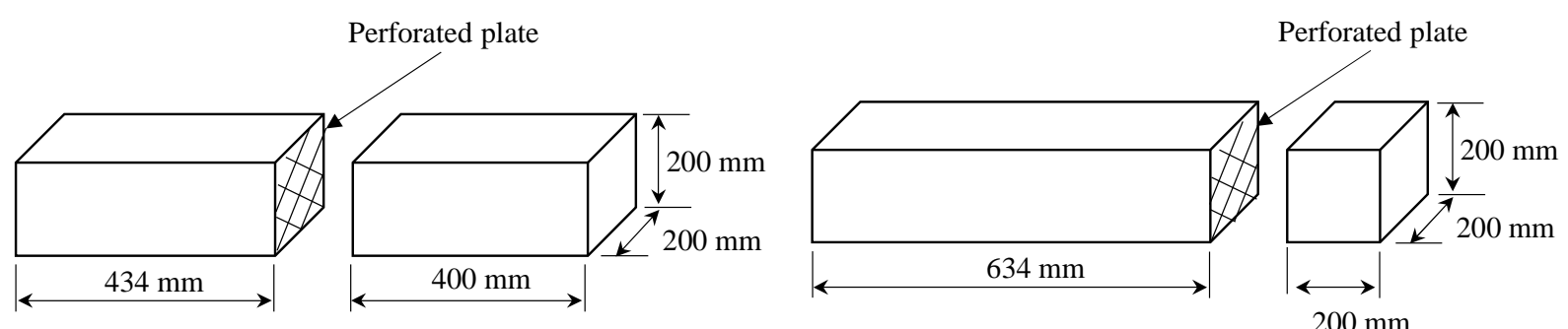

Fig.2 Position of perforated plate.
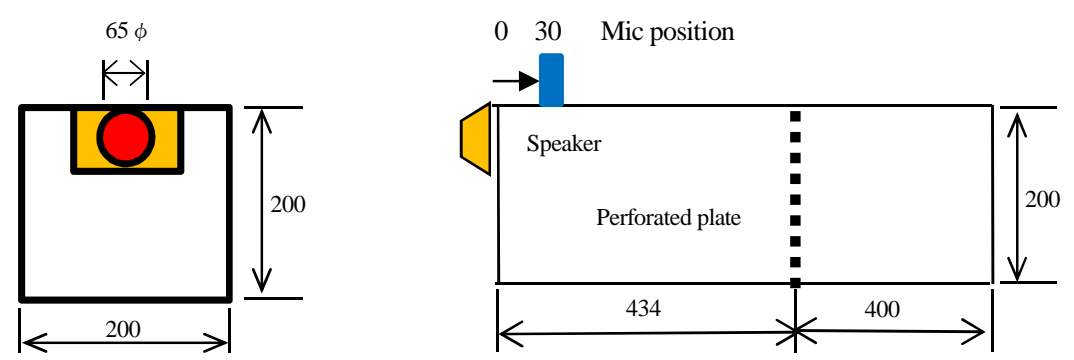

Fig.3 Experimental apparatus.

\section{$3 \cdot 2$ 実験パラメータ}

実験パラメータは穴あき板の開口率で 1\%，4\%，16\%および 100\%（穴あき板無し）で，各開口率に対し穴の 長さ (穴あき板の厚み) は $2.3 \mathrm{~mm}, 4.6 \mathrm{~mm}, 10 \mathrm{~mm}$ および $20 \mathrm{~mm}$ である.ここで用いた穴あき板は厚みが $2.3 \mathrm{~mm}$, $4.6 \mathrm{~mm}$ のものはこれまでの研究で用いた鋼製で穴径 $3 \mathrm{~mm}$ で千鳥配列のものであり, 厚みが $10 \mathrm{~mm}, 20 \mathrm{~mm}$ のも のはアクリル製で穴径 $3 \mathrm{~mm}$ で正方配列のものである.これらの写真を図 4 に示す.

\section{$3 \cdot 3$ 実験方法}

図 2 に示すように長さ $434 \mathrm{~mm}$ と $400 \mathrm{~mm}$ または， $634 \mathrm{~mm}$ と $200 \mathrm{~mm}$ のダクトの間に穴あき板を設置し，パソ コンからランダムノイズを出し，アンプで増幅したのちスピーカから音をダクトに与える. ダクト内の音を図 3 に示した位置に置かれたマイクロホンで拾い，その出力を FFT アナライザー（RION 社製，SA78）に導き，周波 数分析する. 図 5 は周波数分析結果の一例であるが，このような図のピークとなる周波数を音響固有周波数とし た. ここで周波数分解能は $6.25 \mathrm{~Hz}$ である. また，ここでは平面波理論が成り立つ $f=c / 2 b=850 \mathrm{~Hz}$ までに存在する 1 次, 2 次および 3 次の音響固有周波数を求めた。ただし， $b$ はダクトの辺長 $(0.2 \mathrm{~m}), c$ は音速である. ちなみ 
に穴あき板が無い場合の音響固有周波数は長さが $0.834 \mathrm{~m}$ の両端閉の境界条件の音響固有周波数であるから式 (13) で求められる.
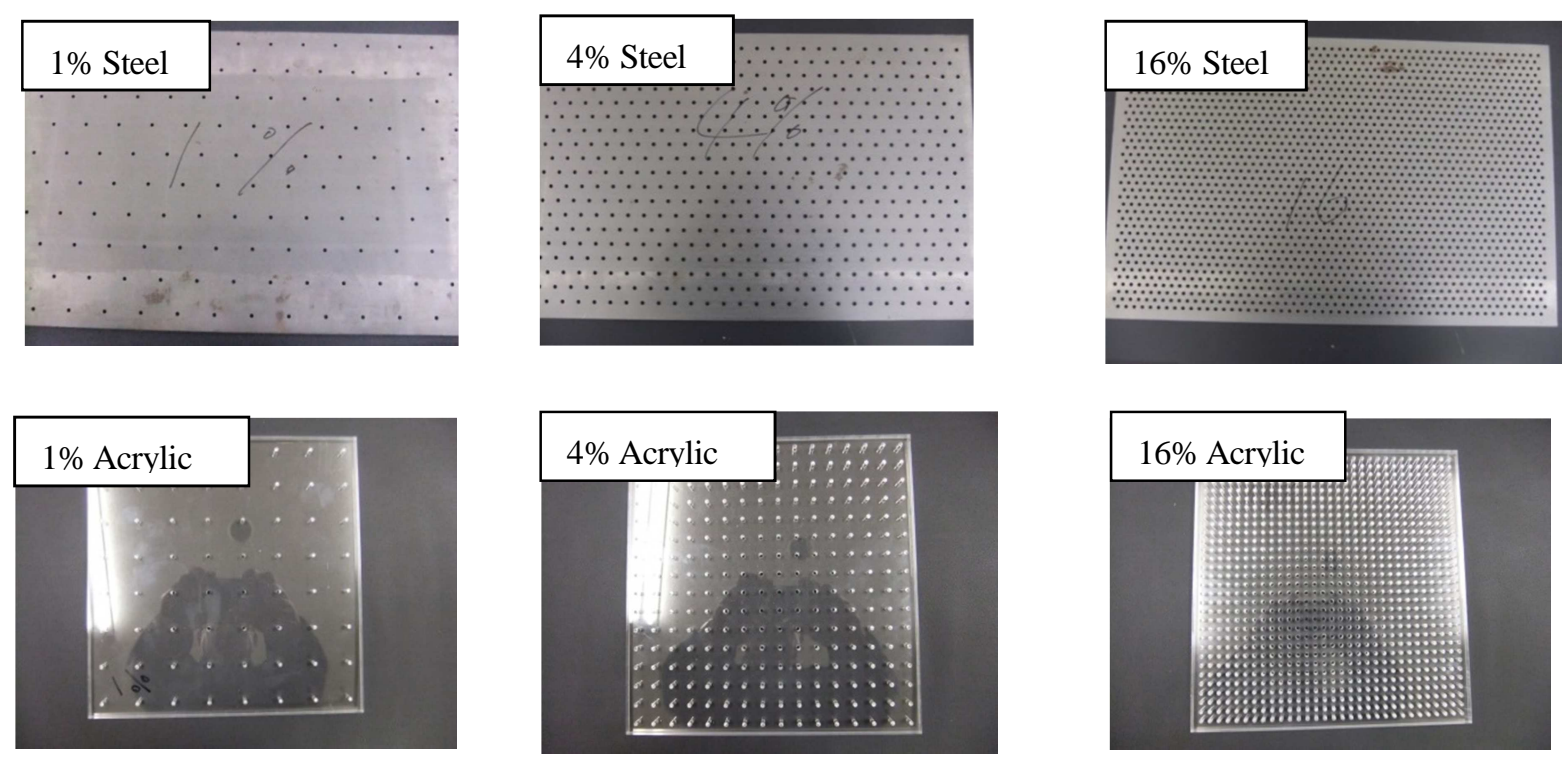

Fig.4 Perforated plates used in this experiment.

$f_{n i}=i \frac{c}{2 l} \quad(i=1,2,3)$

ここで $c, \quad l$ はそれぞれ音速（室温 $20^{\circ} \mathrm{C} て ゙ 343.5 \mathrm{~m} / \mathrm{s} ）$ とダクト長さ $(0.834 \mathrm{~m}$ ）である. したがって 1 次， 2 次， 3 次の音響固有周波数はそれぞれ $205.9 \mathrm{~Hz}, 411.9 \mathrm{~Hz}, 617.8 \mathrm{~Hz}$ となる.一方実験值はそれぞれ $200.0 \mathrm{~Hz}, 425.0 \mathrm{~Hz}$, $618.75 \mathrm{~Hz}$ であり周波数分解能 $6.25 \mathrm{~Hz}$ を考慮すると両者はほぼ一致していると言える.

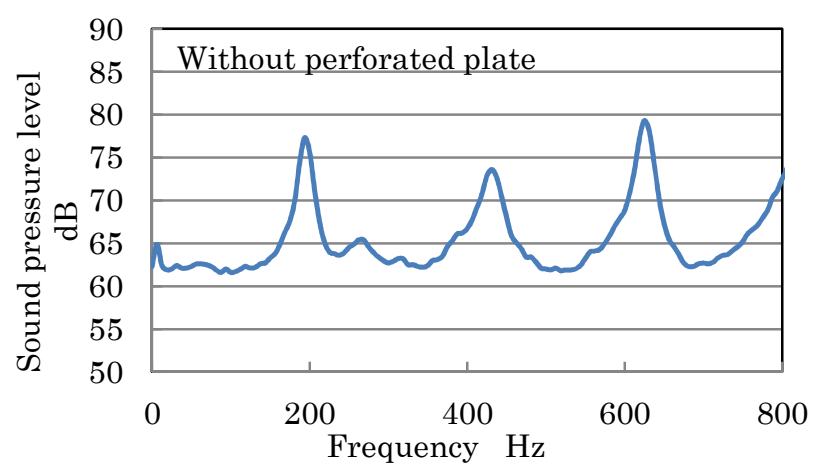

Fig.5 Example of frequency analysis.

\section{4. 実験結果と固有值解析値と応答解析値の比較および考察}

図 6〜図 11 にそれぞれ開口率が 1\%,4\%, および $16 \%$ の場合の穴の長さに対する音響固有周波数の変化を示す. 実線は固有值解析による結果 (以下固有解析值), 点線は応答解析による結果 (以下応答解析值), ○印は実験に よる結果 (以下実験值) を示している. また, 図 6〜図 8 はスピーカより $434 \mathrm{~mm}$ の位置に穴あき板を設置した 場合の結果であり，図 9～図 11 はスピーカより $634 \mathrm{~mm}$ の位置に穴あき板を設置した場合の結果である.すべて の図において実験值はいずれの解析值ともおおむね一致している.しかしながらより詳細にみると低次モード（1 次モード）では応答解析結果が，高次モード（2，3 次モード）では固有值解析結果が実験結果に近い。これら解 析と実験の結果から穴の長さの音響固有周波数に及ぼす影響はこれらの結果から知ることができる。すなわち， 
穴の長さが長くなるほど音響固有周波数は低下し，穴あき板の音響固有周波数へ及ぼす影響は開口率が大きくな るほど少なくなる点である.一般に開口率が約 20\%を超えると音響的には穴あき板がないのと同じであり(石原, 2017)，そうであれば穴の長さの影響が少なくなるのは当然のことである.また，図 6 の開口率が $1 \%$ の結果に示 すように 3 次モードのピークが穴の長さが $0.02 \mathrm{~m}$ のとき生じていないことが分かる. これは穴あき板の設置位置 が粒子速度モードの 3 次の腹になっていることから音響減衰比が大きくなったため 3 次モードが励起されにくい ためである(石原他, 2018). また図6～図 8 において 2 次モードの音響固有周波数が穴の長さが変わっても変化し ていない．これは穴あき板がダクトの 2 次の粒子速度モードの節に置かれているため, 穴の影響が現れないため である.

さらに, 図 6〜図 11 において固有值解析值と応答解析值は同様の傾向を示し，すべての解析条件において応答 解析值の方がわずかに低い值となる傾向を示した．そして，1 次モードに着目するとわずかであるが，応答解析 值の方が固有解析值よりも実験值に近い值を示した. 本研究における固有值解析值と応答解析値の違いは伝達マ トリックス法における穴あき板に対応寸る行列の違いによるものであるが，周波数と穴の長さの範囲によっては その違いはわずかなものとなることを以下で考察する.

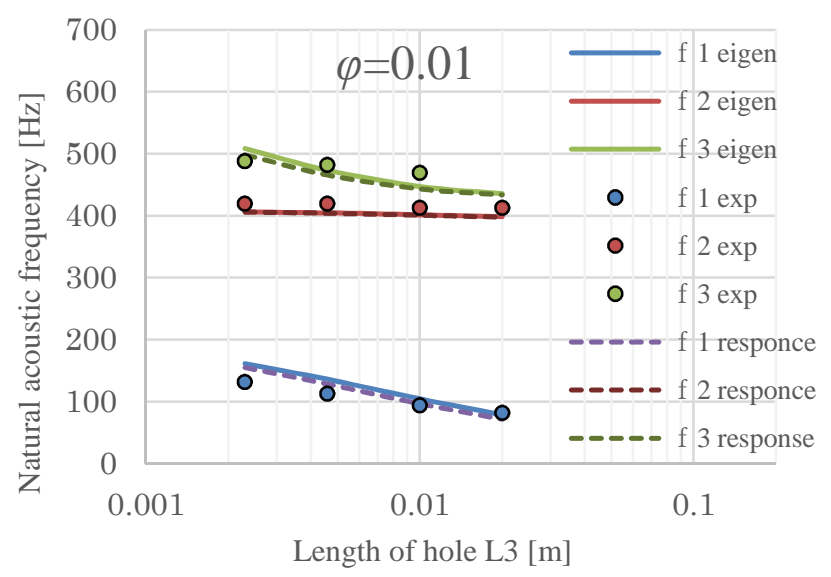

Fig. 6 Comparison of experimental result with two analytical results $\left(l_{1}=434 \mathrm{~mm}, \quad \varphi=0.01\right)$. The acoustic natural frequencies of $1^{\text {st }}$ mode and $3^{\text {rd }}$ mode decreased with increasing the length of the hole. But the effect of the hole length on that of 2 nd mode was not observed.

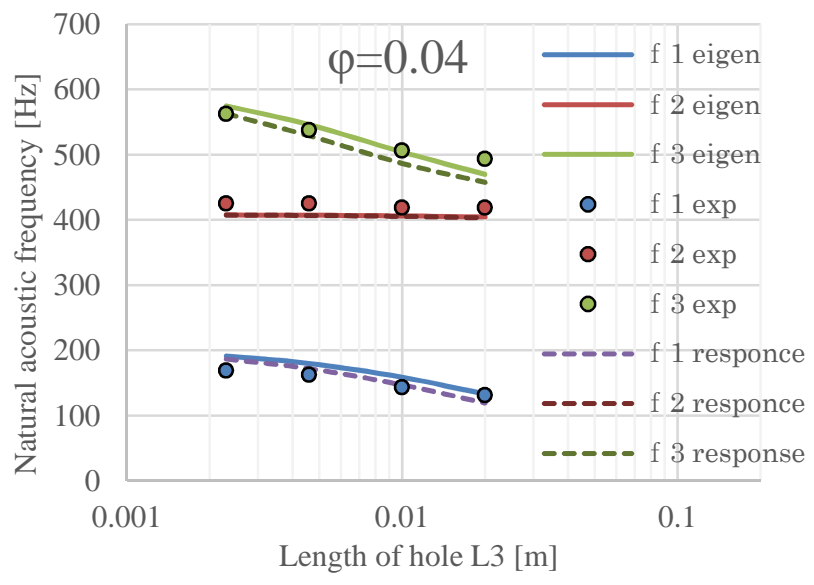

Fig. 7 Comparison of experimental result with two analytical results $\left(l_{1}=434 \mathrm{~mm}, \quad \varphi=0.04\right)$. The acoustic natural frequency of the 1st mode should be solved by the response analysis and that of the $3 \mathrm{rd}$ mode by the eigenvalue analysis in comparison the both analytical results with the experimental one. 


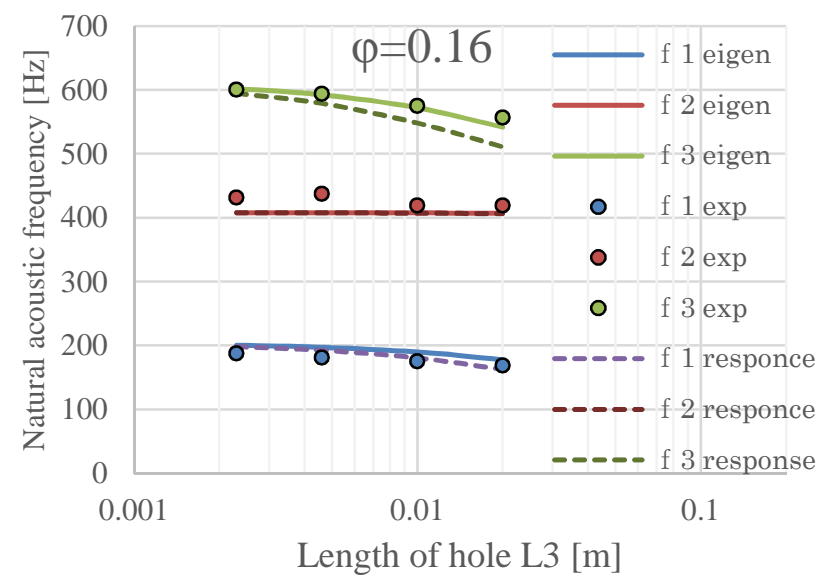

Fig. 8 Comparison of experimental result with two analytical results $\left(l_{1}=434 \mathrm{~mm}, \quad \varphi=0.16\right)$. The acoustic natural frequency of 3rd mode calculated by the eigenvalue analysis was closer to the experimental result than that calculated by the response analysis. And this tendency was remarkable as the hole length was longer.

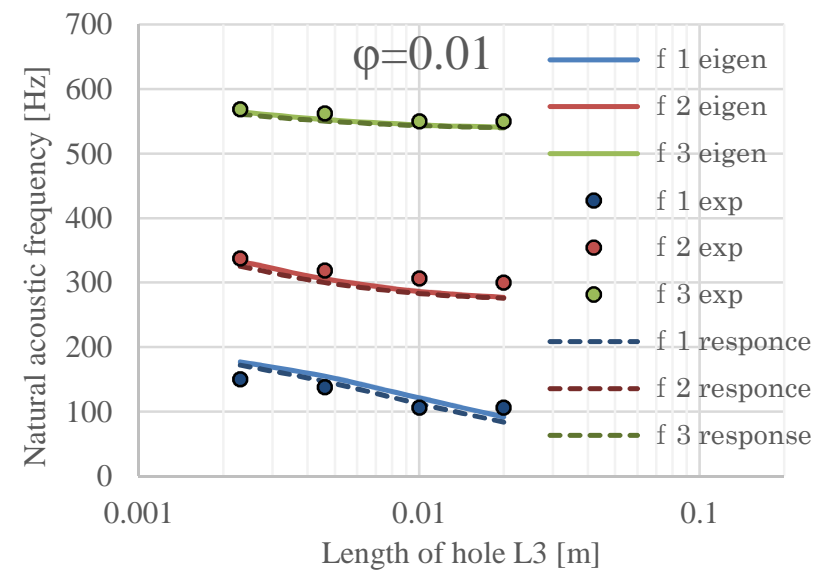

Fig. 9 Comparison of experimental result with two analytical results $\left(l_{1}=634 \mathrm{~mm}, \quad \varphi=0.01\right)$. The acoustic natural frequencies of $1 \mathrm{st}, 2 \mathrm{nd}$ and $3 \mathrm{rd}$ mode decreased with increasing of the hole length. The analytical results by the eigenvalue analysis and those by the response analysis were almost matched for all modes.

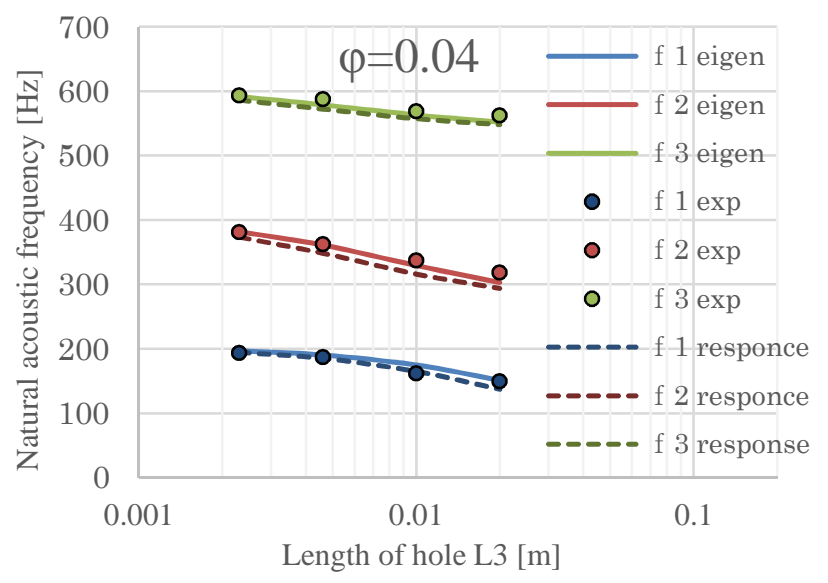

Fig. 10 Comparison of experimental result with two analytical results $\left(l_{1}=634 \mathrm{~mm}, \quad \varphi=0.04\right)$. The acoustic natural frequency of 2 nd mode calculated by the eigenvalue analysis was closer to the experimental result than that by the response analysis for every hole length. 


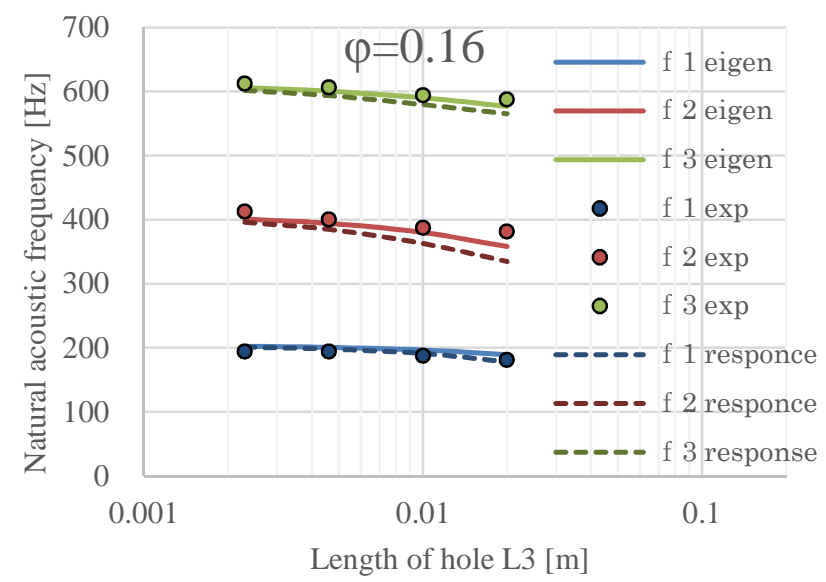

Fig. 11 Comparison of experimental result with two analytical results $\left(l_{1}=634 \mathrm{~mm}, \quad \varphi=0.16\right)$. The acoustic natural frequency of 2 nd mode calculated by the eigenvalue analysis was closer to the experimental result than that calculated by the response analysis. And this tendency was remarkable as the hole length was longer.

\section{5. 固有值解析值および応答解析值における伝達マトリックスの比較}

今回，固有值解析結果，応答解析結果および実験結果はお互いによく一致した。この理由について以下に固有 值解析および応答解析の伝達マトリックス法における行列の要素を比較し検討する. 固有值解析による振動数方 程式は式（4）の絶対值を 0 とおいて得られるものであることを $2 \cdot 1$ 節で示した. 式（4）は $k l_{3}$ が小さいとき $\cos k l_{3} \approx 1, \quad \sin k l_{3} \approx k l_{3}$ または， $\frac{1}{Z_{3}} \sin k l_{3} \approx 0$ であることから式（14）で置き換えられる.

$$
A_{21}=j\left(\frac{1}{Z_{2}} \sin k l_{2} \cos k l_{1}-\frac{Z_{3}}{Z_{1} Z_{2}} k \boldsymbol{l}_{3} \sin k l_{2} \sin k l_{1}+\frac{1}{Z_{1}} \cos k l_{2} \sin k l_{1}\right)
$$

一方，応答解析においてピークとなる振動数は式（11）の分母の $A_{21}$ を極小化する值である. 式 $(11)$ の $A_{21}$ は式（15）であり，これを $A_{21}$ ‘とする.

$$
A_{21}{ }^{\prime}=\frac{Z_{R}}{Z_{1} Z_{2}} \sin k l_{2} \sin k l_{1}+j\left(\frac{1}{Z_{2}} \sin k l_{2} \cos k l_{1}-\frac{Z_{i}}{Z_{1} Z_{2}} \sin k l_{2} \sin k l_{1}+\frac{1}{Z_{1}} \cos k l_{2} \sin k l_{1}\right)
$$

$A_{21}$ と $A_{21}^{\prime}$ の違いは $A_{21}$ にに実部の $\frac{Z_{R}}{Z_{1} Z_{2}} \sin k l_{2} \sin k l_{1}$ があることと, 虚部の第 2 項の係数が $A_{21}$ において $\frac{-Z_{3}}{Z_{1} Z_{2}} k l_{3}$ であ

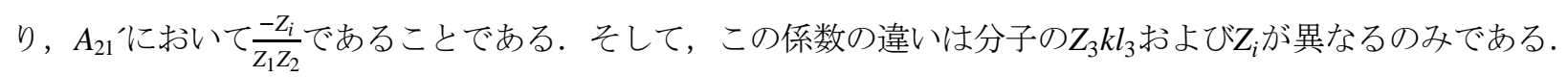
また， $Z_{i}$ は式（9）より

$$
1 \gg \frac{1}{r_{0}} \sqrt{\frac{2 \mu}{\rho \omega}}
$$

となる周波数の範囲において式（17）の最右辺で近似できる.ここで，開口面積で除してあるのは体積速度に対 する抵抗である事を考慮したためである.

$$
Z_{\mathrm{i}}=\frac{\omega \rho l_{3}}{S_{3}}\left[1+\frac{1}{r_{0}} \sqrt{\frac{2 \mu}{\rho \omega}}\right] \approx \frac{\omega \rho l_{3}}{S_{3}}
$$


一方， $Z_{3} k l_{3}$ は式（18）で表され，式（17）と一致することが分かる.

$$
Z_{3} k l_{3}=\frac{\rho c}{S_{3}} \cdot \frac{\omega}{c} l_{3}=\frac{\rho \omega l_{3}}{S_{3}}
$$

式(16)の右辺は周波数 $f$ が $100 \mathrm{~Hz}$, 穴の半径 $r_{0}$ が $1.5 \mathrm{~mm}$, 空気の粘性率が $1.8 \times 10^{-5} \mathrm{pa} \cdot \mathrm{s}$, 空気の密度が $1.2 \mathrm{~kg} / \mathrm{m}^{3}$ とすると，

$$
\frac{1}{r_{0}} \sqrt{\frac{2 \mu}{\rho \omega}}=\frac{1}{1.5 \times 10^{-3}} \sqrt{\frac{2 \times 1.8 \times 10^{-5}}{1.2 \times 2 \times 3.14 \times 100}} \approx 0.146
$$

であり，式（16）の条件を満たすことが分かる．よって周波数が $100 \mathrm{~Hz}$ 以上では式（15）の近似が可能であるこ とが分かる.

そのため, $A_{21}{ }^{\prime}$ の実部が大きくなるほど固有值解析と応答解析の結果に差が生じると予測される. この差は $A_{21}$ と $A_{21}{ }^{\prime}$ を複素平面に表示寸るとわかりやすい. 図 12 に $A_{21}$ と $A_{21}{ }^{\prime}$ の関係を示寸. また, $A_{21}$ ' は複素数であり周波数, 寸なわち波数 $k$ の変化によってその值は変化する. その軌跡を図 13 に示寸. 図 13 より $A_{21}{ }^{\prime}$ の実部は虚部に比心゙ 十分小さく，虚部が 0 になるとき実部もほぼ 0 となることが分かる．そのため， $\left|A_{21}\right|$ が 0 となるような周波数に おいて $\left|A_{21}\right|$ もほぼ 0 となり音響固有振動数はほぼ等しくなる. 次に図 14 に応答解析において音圧レベルの 1 次, 2 次, 3 次のピークに対応する $A_{21}{ }^{\prime}$ の複素平面上の位置を示寸. この図は図 13 の実軸を拡大して示したものであ る. 周波数が 0 のとき複素座標は原点にあって周波数が上がるにつれて図のような軌跡を描く. 一次モードに対 応する位置を○，2 次モードに対応する位置を $\mathbf{\Delta}, 3$ 次モードに対応する位置をロで示している，いずれの位置も $A_{21}{ }^{\prime}$ の虚部がほぼ 0 となる位置である事が確認できる.

今回の実験と解析に用いたモデルにおいて, 二つの解析結果はほぼ等しい值を示し実験結果ともよく一致した. 本実験によって, 本研究に用いた穴あき板の穴の長さや開口率の範囲であれば固有值解析, 応答解析のどちらを 用いても固有振動数を計算することが可能であることがわかった.

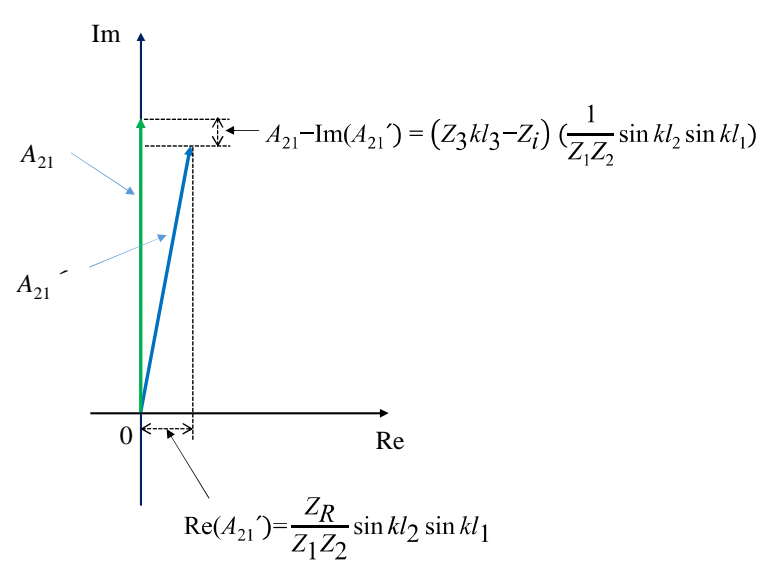

Fig. 12 Relationship of $A_{21}$ and $A_{21}$ '. The differences of the real part and the imaginary part between $A_{21}$ and $A_{21}{ }^{\prime}$ were indicated on the complex plane.

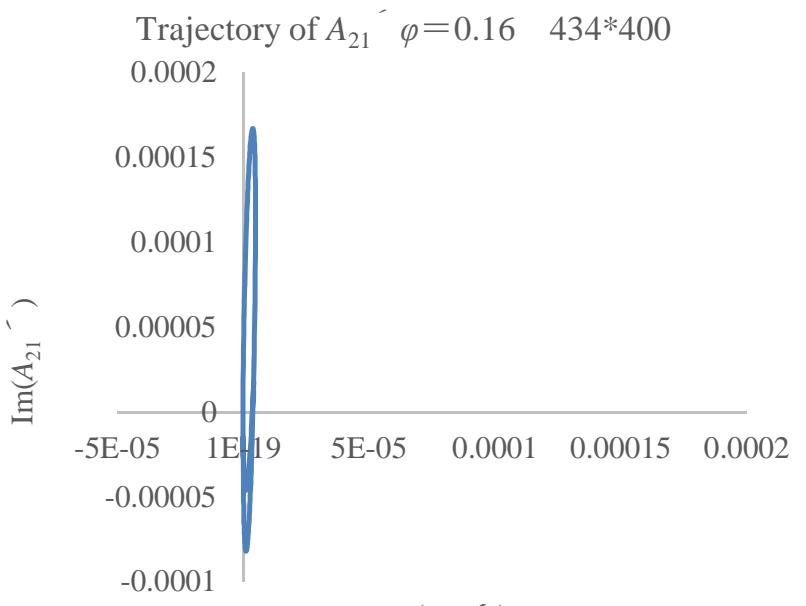

$\operatorname{Re}\left(A_{21}{ }^{-}\right)$

Fig. 13 Trajectory of $A_{21}$ ' by changing of frequency. The trajectory of $A_{21}$ 'with changing the frequency is indicated in figure 13. The real part of $A_{21}$ is very smaller than the imaginary part of $A_{21}^{\prime}$. 


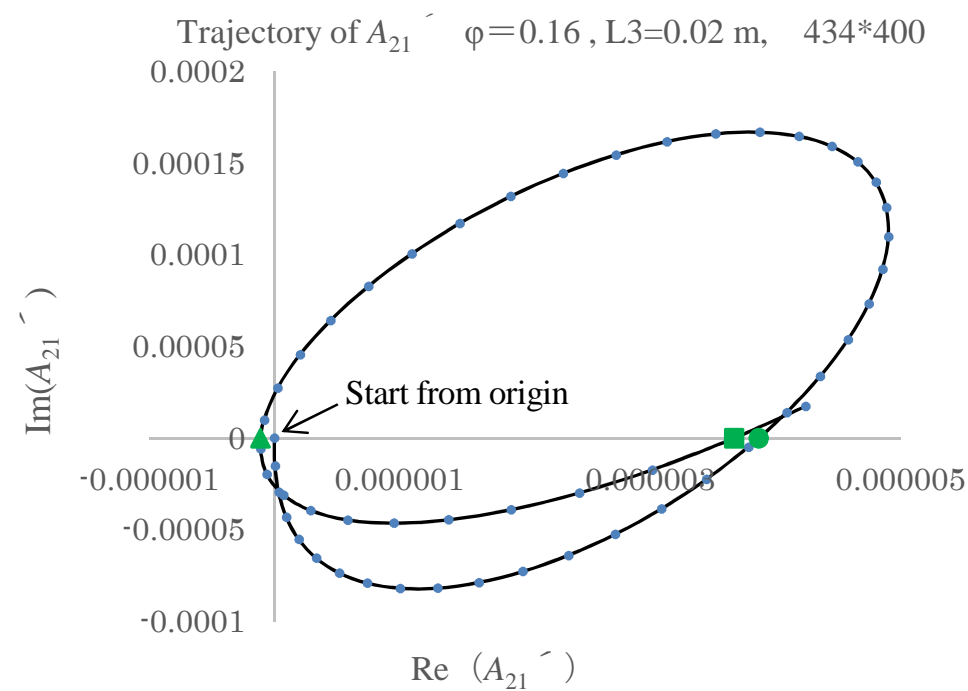

Fig. 14 Position of $A 21^{\prime}$ corresponding to acoustic natural frequency. $A_{21}$ ' corresponding to the acoustic natural frequencies of 1 st ,2nd and 3rd modes are indicated by $\boldsymbol{O}, \boldsymbol{\Delta}, \mathbf{v}$ respectively. It can be confirmed that the imaginary part of these $A_{21}{ }^{`}$ is nearly zero.

\section{6. 応答解析による音響固有周波数が固有值解析によるそれより小さくなる理由}

前章では固有值解析と応答解析による音響固有周波数の差はわずかであり，両者は実験值とよく一致すること を示した. しかしながら 4 章において「図 6〜図 11 において音響固有周波数の固有值解析值と応答解析值は同様 の傾向を示し，すべての解析条件において応答解析值の方がわずかに低い值となる傾向を示した.」と述べたので 本章ではその理由について検討する。

はじめに式 (4) を $k l_{3}$ が小さいとき, $\cos k l_{3} \approx 1, \sin k l_{3} \approx k l_{3}$ または, $\frac{1}{z_{3}} \sin k l_{3} \approx 0$ として近似した式（14）と比 較する. 一例として $l_{1}=0.434 \mathrm{~m}, \quad l_{2}=0.4 \mathrm{~m}, \quad l_{3}=0.02 \mathrm{~m}, \quad \varphi=0.04$ についての計算結果を図 15 に示す. 図 15 より式 (4)と式（14）は全く重なっており近似による誤差は無視してよいことが明らかになったこのことはすべての条 件で計算し確認している. 寸なわち式（4）と式（14）は同一とみなしてよい.

次に応答解析における式（11）の分子は数值解析的にも理論的にも-1 となり, 応答がピークとなる周波数は式 (15)の絶対值が極小となるときのそれである. 前章において式（15）は実数部と虚数部が存在し，応答が最大と なるときの虚数部はほぼ 0 に近く, 実数部も非常に小さいことを示した. そこで式（15）の虚数部を計算し, 図

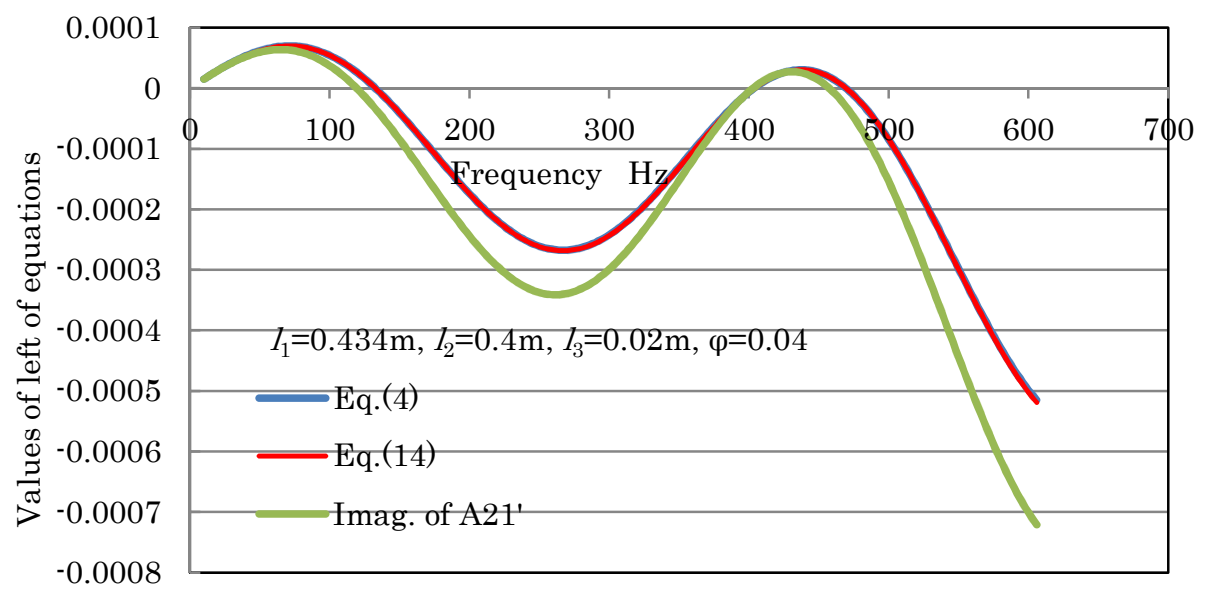

Fig. 15 Comparison of each expressions of eigenvalue equation. Eq.(4) and Eq.(14) are totally overlapping, it can be confirmed that Eq.(4) and Eq.(14) are match. On the other hand, the imaginary part of $A_{21}$ 'and Eq.(4) is not matched. And the intersection point of the imaginary part of $A_{21}{ }^{\prime}$ with the frequency axis, these indicate the acoustic natural frequencies, are smaller than those of Eq.(4) for the 1st and 3rd modes . 
15 の上に示すと緑色で示す線のようになった。これをみると式（15）の虚数部は式（4）と式（14）とは異なっ ており, また周波数軸と交差する点（音響固有周波数）がその他の線が交差する点に比べて 1 次, 3 次モードで 小さくなっていることがわかる. 2 次モードはほとんど同じである.このことは計算条件が同じである図 7 の結 果と全く同じである.すなわちこの段階で音響固有周波数の応答解析值が固有值解析值より小さくなる理由が明 らかになった。つまり応答解析による音響固有周波数が固有值解析によるそれより小さくなるのは式（15）の実 数部の影響ではないと言える.したがって式（17）を導く際に用いた近似は誤差を生む原因となる.

減衰のある一次元音場の応答解析では式(15)の絶対值が極小值をとる周波数が音響固有周波数となる.式(15)

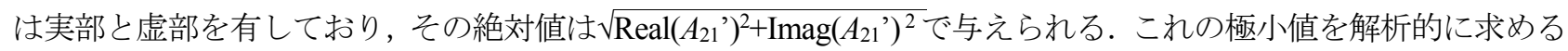
のは困難なのでここでは実数部の音響固有周波数へ及ぼす影響が無視できることを振動解析により示す.

一般に一次元ダクト音場は棒とみなせる. したがって棒の縦振動を考える. 棒の縦振動の運動方程式は変位を u とすると，式（20）で与えられる.

$$
-\rho A \frac{\partial^{2} u}{\partial t^{2}}+A E \frac{\partial^{2} u}{\partial x^{2}}=0
$$

ここで $\rho ， \mathrm{~A} ， \mathrm{E}$ は棒のそれぞれ密度，断面積，ヤング率である.

この式に単位面積，単位長さ当たりの粘性係数を c $\left(\mathrm{N} ・ \mathrm{~S} / \mathrm{m}^{4}\right)$ を考慮すれば,

$$
-\rho A \frac{\partial^{2} u}{\partial t^{2}}-c A \frac{\partial u}{\partial t}+A E \frac{\partial^{2} u}{\partial x^{2}}=0
$$

両辺を $\rho A$ で除すと，

$$
\begin{gathered}
\frac{\partial^{2} u}{\partial t^{2}}+\gamma \frac{\partial u}{\partial t}-\frac{E}{\rho} \frac{\partial^{2} u}{\partial x^{2}}=0 \quad \text { ただし }, \gamma=\frac{c}{\rho} \\
\text { ここで } a^{2}=\frac{E}{\rho} \text { とおけば, } \\
\frac{\partial^{2} u}{\partial t^{2}}+\gamma \frac{\partial u}{\partial t}-a^{2} \frac{\partial^{2} u}{\partial x^{2}}=0 \\
u_{i}(x, t)=\varphi_{i}(x) \cdot q_{i}(t) \quad(i: \text { モードの次数 }) \quad \text { とおいて式(22)に代入すると } \\
\varphi_{i} \frac{\mathrm{d}^{2} q_{i}}{\mathrm{~d} t^{2}}+\gamma \varphi_{i} \frac{\mathrm{d} q_{i}}{\mathrm{~d} t}-a^{2} \frac{\mathrm{d}^{2} \varphi_{i}}{\mathrm{~d} x^{2}} \cdot q_{i}=0
\end{gathered}
$$

両辺に $\varphi_{j}$ を掛けて $0 〜 l$ まで積分すると

$$
\begin{aligned}
& \int_{0}^{l} \varphi_{i} \varphi_{j} \cdot \mathrm{d} x \frac{\mathrm{d}^{2} q_{i}}{\mathrm{~d} t^{2}}+\gamma \int_{0}^{l} \varphi_{i} \varphi_{j} \cdot \mathrm{d} x \frac{\mathrm{d} q_{i}}{\mathrm{~d} t}-a^{2} \int_{0}^{l} \frac{\mathrm{d}^{2} \varphi_{i}}{\mathrm{~d} x^{2}} \cdot \varphi_{j} \cdot \mathrm{d} x \cdot q_{i}=0 \\
& \text { モードの直交性より } \int_{0}^{l} \varphi_{i} \varphi_{j} \cdot \mathrm{d} x= \begin{cases}i \neq j & 0 \\
i=j & A\end{cases}
\end{aligned}
$$


また，部分積分を行い境界条件 $\varphi_{i}(0)=\varphi_{j}(l)=0$ を考慮すると

$$
\int_{0}^{l} \frac{\mathrm{d}^{2} \varphi_{i}}{\mathrm{~d} x^{2}} \cdot \varphi_{j} \cdot \mathrm{d} x=\left.\frac{\mathrm{d} \varphi_{i}}{\mathrm{~d} x} \cdot \varphi_{j}\right|_{0} ^{l}-\int_{0}^{l} \frac{\mathrm{d} \varphi_{i}}{\mathrm{~d} x} \cdot \frac{\mathrm{d} \varphi_{j}}{\mathrm{~d} x} \mathrm{~d} x=-\int_{0}^{l}\left(\frac{\mathrm{d} \varphi_{i}}{\mathrm{~d} x}\right)^{2} \mathrm{~d} x=-\mathrm{B}
$$

したがって

$$
A_{i} \frac{\mathrm{d}^{2} q_{i}}{\mathrm{~d} t^{2}}+\gamma A_{i} \frac{\mathrm{d} q_{i}}{\mathrm{~d} t}+a^{2} B_{i} \cdot q_{i}=0
$$

$$
\frac{\mathrm{d}^{2} q_{i}}{\mathrm{~d} t^{2}}+\gamma \frac{\mathrm{d} q_{i}}{\mathrm{~d} t}+a^{2} \frac{B_{i}}{A_{i}} \cdot q_{i}=0
$$

ここで $a^{2} \frac{B_{i}}{A_{i}}=\omega_{i}^{2}, \quad \gamma=2 \zeta_{i} \omega_{i}$ とおけば

$$
\frac{\mathrm{d}^{2} q_{i}}{\mathrm{~d} t^{2}}+2 \zeta_{i} \omega_{i} \frac{\mathrm{d} q_{i}}{\mathrm{~d} t}+\omega_{i}^{2} \cdot q_{i}=0
$$

式（26）の解は

$$
q_{i}=\exp \left(-\zeta_{\mathrm{i}} \omega_{\mathrm{i}}\right) \sin \omega_{\mathrm{di}} \mathrm{t}
$$

となり減衰付固有円振動数は

$$
\omega_{\mathrm{di}}=\omega_{\mathrm{i}} \sqrt{1-\zeta_{i}^{2}}
$$

となる. 一般に $\zeta_{\mathrm{i}}$ は $10^{-1} \sim 10^{-2}$ のオーダーであるから式（28）から $0.995 \sim 0.99995$ となり, 減衰の固有振動数に 及ぼす影響は無視できると言える。

\section{7. 結}

一次元音場における固有音響周波数の解析方法について, 伝達マトリックス法を用いて固有値解析と応答解析 を比較した．その結果以下の知見を得た。

(1) 固有值解析により計算した音響固有周波数と応答解析により計算したそれはほぼ一致しており，どちらの解 析結果も実験結果とよく一致することが分かった。しかしながらより詳細にみると低次モード（1 次モード） では応答解析結果が，高次モード（2，3 次モード）は固有值解析結果が実験結果に近いことが言える.

（2）応答解析に Melling が導出した音響インピーダンスを適応した場合, 伝達マトリックスの非対角要素に実部を 含む複素数が現れるがその実部は非常に小さいため, 固有值解析によって求められる音響固有周波数とほぼ一 致する.したがっていずれの解析方法も一次元音場における音響固有周波数の推定に用いることが可能である.

(3) また応答解析による音響固有周波数 $f_{\mathrm{n}}$ が固有値解析による $f_{\mathrm{n}}$ よりすべての条件で小さく現れる点に着目して 検討を加えた. その結果 $f_{\mathrm{n}}{ }^{\prime}<f_{\mathrm{n}}$ となるのは応答の式において分子が-1 となりしたがって分母が極小值をとる周 波数が $f_{\mathrm{n}}$ 'となるが，その差は $Z_{3} k l_{3}$ を $Z_{\mathrm{i}}$ に置き換えたために生じたものであることが明らかになった. 


\section{文献}

石原国彦，ボイラ管群ダクトで発生する大音響騒音の穴あき板を利用した対策法に関する研究(限界開口率の把 握と空洞部体積の抑制効果に及ぼす影響)，日本機械学会論文集，Vol. 83，No. 848 (2017)，DOI: 10.1299/transjsme. 16-00456.

石原国彦，工藤哲，穴あき板で仕切られた一次元音場の共鳴周波数に関する研究，日本機械学会論文集，Vol.85, No.871(2019), DOI:10.1299/transjsme.18-00305.

石原国彦，工藤哲，栘本貴之，森正明，穴あき板で仕切られた 1 次元音場の共鳴周波数(解析と実験の比較), 日本 機械学会中国四国支部第 55 期総会・講演会講演論文集(2017), ID: K1114.

石原国彦，工藤哲，栘本貴之，森正明，穴あき板で仕切られた 1 次元音場の共鳴周波数と音圧モードに関する研 究, 日本機械学会論文集, Vol.84, No.857(2018), DOI:10.1299/transjsme. 17-00365.

石原国彦，中岡正典，西岡幹人，ボイラ管群ダクトで発生する大音響騒音の対策法としての穴あき板の利用に関 する研究 (開口率 1\%以上の場合), 日本機械学会論文集, Vol. 82, No. 841(2016),DOI: 10.1299/transjsme. 16-00179.

木村康正, 山口善三, 坂谷亨, 圧縮機用多孔板型消音器, 神戸製鋼技報, Vol.59, No.3 (2009), pp.13-16.

工藤哲, 石原国彦, 穴あき板で仕切られた 1 次元音場の共鳴周波数に及ぼす穴あき板の影響, 日本機械学会第 27 回環境工学総合シンポジウム講演論文集(2017), ID: 111.

工藤哲, 石原国彦, 穴あき板の設置位置が 1 次元音場の共鳴周波数に及ぼす影響, 日本機械学会第 28 回環境工学 総合シンポジウム講演論文集(2018), ID: 128.

Melling, T. H., The acoustic impedance of perforates at medium and high sound pressure levels, Journal of Sound and Vibration, Vol.29, No.1 (1973), pp.1-65.

次橋一樹, 山極伊知郎, 菊池政寛, 微細多孔吸音板を含む音場のシミュレーション技術と製品開発への適用, 神戸 製鋼技報, Vol.64, No.2(2014), pp.90-95.

\section{References}

Ishihara, K., Study on a countermeasure for high level sound generated from boiler tube bank duct using walls made of perforated plate (Grasp critical aperture ratio and influence of cavity volume on suppression effect), Transactions of the JSME (in Japanese), Vol.83, No.848 (2017), DOI: 10.1299/transjsme. 16-00456.

Ishihara, K. and Kudo, S., Study on acoustic natural frequency of one dimensional sound field partitioned by perforated plate, Transactions of the JSME (in Japanese), Vol.85, No.871 (2019), DOI:10. 1299/transjsme. 18-00305.

Ishihara, K., Kudo, S., Masumoto, T. and Mori, M., Acoustic natural frequency of one dimensional sound field partitioned by perforated plate (comparison between analysis and experiment), Proceedings of the 55th Annular Meeting in Chugoku-Shikoku (2017), ID: K1114 (in Japanese).

Ishihara, K., Kudo, S., Masumoto, T. and Mori, M., Study on acoustic natural frequency and its mode of one dimensional sound field partitioned by perforated plate, Transactions of the JSME (in Japanese), Vol.84, No.857 (2018), DOI:10. 1299/transjsme. 17-00365.

Ishihara, K., Nakaoka, M. and Nishioka, M., Study on a countermeasure for high level sound generated from boiler tube bank duct using walls made of perforated plate (In case of aperture ratio being more than 1\%), Transactions of the J SME (in Japanese), Vol.82, No.841 (2016), DOI: 10.1299/transjsme. 16-00179.

Kimura, Y., Yamaguchi, Z. and Sakatani, T., Perforated panel type silencer for screw compressors, Kobe Steel Engineering Reports, Vol.59, No.3 (2009), pp.13-16(in Japanese).

Kudo, S. and Ishihara, K., Effect of perforated plate on acoustic natural frequency of one dimensional sound field partitioned by perforated plate, 27th Environment engineering symposium paper (2017), ID: 111(in Japanese).

Kudo, S. and Ishihara, K., Effect of set position of perforated plate on acoustic natural frequency of one dimensional sound field, 28th Environment engineering symposium paper (2018), ID: 128(in Japanese).

Melling, T. H., The acoustic impedance of perforates at medium and high sound pressure levels, Journal of Sound and Vibration, Vol.29, No.1 (1973), pp.1-65.

Tsugihashi, K., Yamagiwa, I. and Kikuchi, M., Research on numerical analysis technique for sound fields including perforated plate, Kobe Steel Engineering Report, Vol.64, No.2(2014), pp.90-95(in Japanese). 